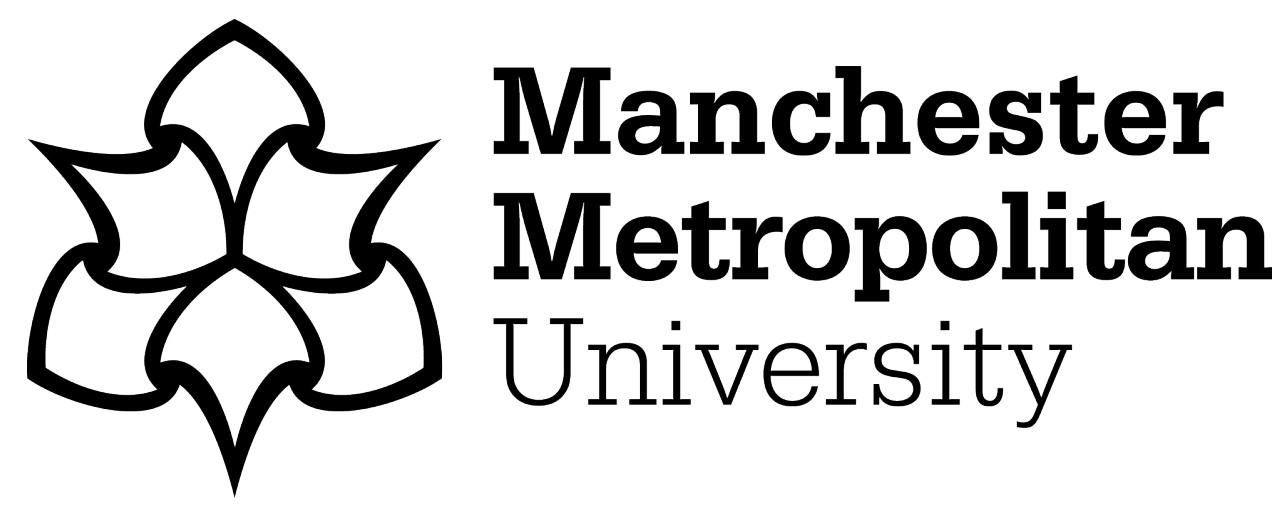

de Trincheria, J, Leal Filho, Walter and Otterpohl, R (2018) Towards a universal optimization of the performance of sand storage dams in arid and semi-arid areas by systematically minimizing vulnerability to siltation: A case study in Makueni, Kenya. International Journal of Sediment Research, 33 (3). pp. 221-233. ISSN 1001-6279

Downloaded from: https://e-space.mmu.ac.uk/627235/

Version: Accepted Version

Publisher: Elsevier

DOI: https://doi.org/10.1016/j.ijsrc.2018.05.002

Usage rights: Creative Commons: Attribution-Noncommercial-No Derivative Works 4.0

Please cite the published version 
Original Research

\title{
Towards a universal optimization of the performance of sand storage dams in arid and semi-arid areas by systematically minimizing vulnerability to siltation: A case study in Makueni, Kenya
}

\author{
Josep de Trincheria a,b, ${ }^{a}$, Walter Filho Leal ${ }^{b}$, Ralf Otterpohl a \\ a Institute of Wastewater Management and Water Protection, Hamburg University of Technology, Hamburg, Germany \\ b Research and Transfer Centre "Sustainable Development and Climate Change Management", Hamburg University of Applied Sciences, Hamburg, Germany
}

a r t i c l e i n fo

\section{Article history:}

Received 7 February 2017

Received in revised form

26 February 2018

Accepted 7 May 2018

Available online 9 May 2018

Keywords:

Bedload transport variability

Spillway

Multi-stage construction

\begin{abstract}
a b s tract
Sand storage dams are hydraulic retention structures that increase the volume of coarse sediments in seasonal sandy streams by exclusively blocking the bedload transport during runoff events. However, siltation of fine grain particles, which are transported as part of the suspended load, is a major factor causing sand storage dams to perform poorly. Therefore, this study aimed to evaluate the hydrological performance and cost-efficiency of 30 sand storage dams. This study also aimed to increase the understanding of critical factors which may affect the performance and lead to siltation of sand storage reservoirs. The analysis was based on a physical survey of 30 sand storage dams that were built in onestage in southeastern Kenya. Most of the study sites had the capacity to produce sand. However, the reservoirs suffered from severe siltation, which caused generalized low annual yields, reduced supply capacities, and low cost-efficiency. It is argued that the main factors for the poor performance were the high inter- and intra-annual variability of bedload transport, which coupled with the construction of onestage spillways, led to siltation of the reservoirs. Thus, large volumes of fine grain particles accumulated in the reservoirs during runoff events with bedload layer heights lower than the height of the one-stage spillways. To systematically maximize the robustness to the inherent variability of bedload transport, and ensure optimal performance levels by systematically minimizing siltation, spillways should be built in stages of reduced height. Thus, the lower the stage height, the higher the probability of maximizing the accumulation of coarse sediment. It is estimated that a multi-stage construction process with stage heights of $20 \mathrm{~cm}$ would have produced a performance 26 times higher. This implies that the 30 reservoirs would have had the capacity to supply 8516 people as compared to the current supply capacity of 330 people. Improvements in the performance of sand storage dams can greatly assist attempts to link this technology with income-generating activities for agropastoralists in arid and semi-arid areas.
\end{abstract}

\& 2018 International Research and Training Centre on Erosion and Sedimentation/the World Association for Sedimentation and Erosion Research. Published by Elsevier B.V. All rights reserved.

\section{Introduction}

The use of integrated rainwater harvesting practices can pro- vide an essential contribution towards food security, poverty reduction, and climate resilience in arid and semi-arid areas (Rockström \& Falkenmark, 2015). Seasonal sandy streams are important water sources in arid and semi-arid areas, because runoff accumulates in specific underground sections of the riv- erbed developing natural shallow groundwater reservoirs (Hussey, 2007; Nissen-Petersen, 2006). If necessary, further development of

\footnotetext{
* Corresponding author.

E-mail address: josepm.trinxeria@gmail.com (J. de Trincheria).
}

these water reservoirs can be carried out using sand storage dams (Hussey, 2007; Lasage et al., 2008; Lasage et al., 2015; Nilsson, 1988; Nissen-Petersen, 2000, 2006; Wipplinger, 1958). Sand sto- rage dams are hydraulic retention structures that increase the volume of coarse sediments in a seasonal sandy stream by max-imizing the exclusive accumulation of the bedload (De Trincheria et al., 2015; De Trincheria et al., 2016). Thus, the coarse sediments accumulated increase the volume of the sub-surface sand reservoir and its role as a runoff storage mechanism and water source to nearby riparian communities during dry periods.

Currently, the water yielded by sand storage dams is predominantly used for domestic uses and livestock, and, to a lesser extent, for off-season small-scale irrigation (Hut et al., 2008) and other income-generating activities (Tuinhof et al., 2012). In 
addition, sand storage dams are a highly cost-efficient rural water supply technology, as they can yield large volumes of water during dry periods at low cost (Lasage et al., 2008, 2015), as compared to other rainwater harvesting technologies (Lasage \& Verburg, 2015). Furthermore, sand storage dams have been implemented in arid and semi-arid areas all over the world, but with a higher frequency in the African continent in general, and Kenya in particular (Nils- son, 1988; Nissen-Petersen, 2000, 2006). Thus, southeastern Kenya is a global hotspot with regard to the use of this technology, where an excess of 3000 sand storage dams have been reported to be built since 1950 (Viducich, 2015). In addition, the design and construction processes used in southeastern Kenya have been promoted and disseminated as a best-practice model, and repli- cated and transferred to other areas of sub-Saharan Africa, southeast Asia, and Latin America (De Trincheria et al., 2015; Nilsson, 1988).

There is little scientific evidence on the real-life performance and cost-efficiency of one-stage sand storage dams based on field data (Ochieng et al., 2008). Also, very few attempts have been made to scientifically analyze the factors which affect the perfor- mance and cost-efficiency of sand storage dams (De Trincheria et al., 2015, 2016; Nissen-Petersen, 2011; Viducich, 2015; Wipplinger, 1958). In this study performance is understood as the capacity of the sand reservoirs in the riverbed to store sand, yield water, and supply local communities. Among the factors that affect the per-formance and cost-efficiency of sand storage dams, siltation of fine grain particles transported as part of the suspended load has been proposed to be the major factor causing sand storage dams to perform poorly (De Trincheria et al., 2016; Wipplinger, 1958). Thus, despite the general success stories associated with sand storage dams, high frequencies of sand storage dams being severely affected by fine particle siltation have been reported for decades (Baurne, 1984; Hussey, 2007; Hut et al., 2008; Nissen-Petersen,

2000, 2006, 2011; Ochieng et al., 2008; Wipplinger, 1958).

Wipplinger (1958), Nissen-Petersen (2000, 2006, 2011) and De Trincheria et al. (2016) have argued that the major cause for sil- tation is associated with the one-stage spillway design. It has been proposed, at least since 1950, that the basic design principle in order to maximize the accumulation of coarse particles and avoid siltation is to build the spillway in stages of reduced height until reaching the final spillway height (Baurne, 1984; De Trincheria et al., 2016; Nilsson 1988; Nissen-Petersen, 2000, 2006, 2011; Ochieng et al., 2008; Wipplinger, 1958). However, there is no consensus on a systematic strategy to avoid siltation. As a result, there is currently an absolute predominance of sand storage dams in arid and semi-arid areas in general, and Kenya in particular, which are built in one-stage (De Trincheria et al., 2015, 2016).

Therefore, the main aim of this study is to evaluate the hydrological performance and cost-efficiency of 30 one-stage sand storage dams in Makueni, southeastern Kenya. Furthermore, this study also aims to increase understanding of the key factors which may have an effect on the performance and siltation of sand sto- rage dams. In order to achieve these goals, the following specific objectives are pursued:

- To evaluate the sand storage capacity, water yield, supply capacity, and cost-efficiency of the sand storage reservoirs evaluated.

- To analyze the factors that influence the performance of the sand storage dams.

- To analyze the factors influencing siltation of the sand storage dams.

- To give practical recommendations in order to minimize siltation, and systematically optimize the performance and benefits of sand storage dams in arid and semi-arid areas.

\section{Materials and methods}

\subsection{Study area}

Kikumbulyu is an administrative area of Makueni County in southeastern Kenya. The County has a bimodal rainfall distribution of 300 - 500 mm (GoK, 2012a, 2012b). Rainfall, runoff, and sedi- ment transport are variable and erratic, with a poor temporal and spatial distribution both inter- and intra-annually (Gichuki, 2000; GoK, 2012a, 2012b; Rocheleau et al., 1995). In addition, drought is a recurrent phenomenon with increasing frequency (Pachauri et al., 2014). Local communities strongly depend on livestock and smallscale farming, but these livelihood activities are severely constrained by the irregular distribution of rainfall and lack of reliable water sources (Rocheleau et al., 1995). Fig. 1 shows the study area and sand storage dams evaluated in 2012 and 2015. In this study an evaluation was done for 30 sand storage dams out of the total 48 sand storage dams implemented in 2015 in Kikumbulyu.

The study area was selected after an extensive on-the-ground survey across southeastern Kenya because a large number of sand storage dams had been built in the last 50 years by multiple organizations in 4 different watersheds. Further, the watersheds presented different geological capacities to produce sand sediment and were distributed across more than $400 \mathrm{~km}^{2}$. Therefore, the study area was considered to include different hydro-geological conditions and construction techniques that were representative and relevant for arid and semi-arid areas in Kenya and the African continent. Furthermore, several of the sand storage dams were apparently affected by siltation despite the capacity to produce sand sediment in the watershed. Therefore, the study area pro- vided an opportunity to evaluate the factors that may affect the performance of sand storage dams in watersheds with different capacities to produce sand sediment.

\subsection{Methods}

Relevant hydrogeological and structural variables were measured on-the-ground in 2012 and 2015 by means of a physical survey. The physical survey was coupled with a total of 77 ran- domized semi-structured interviews with at least two adult community members available at each study site. The data col- lected was subsequently analyzed to determine the sand storage capacity, water yield, and water supply capacity, and cost-effi- ciency of the sand storage reservoirs evaluated. In addition, a correlation analysis between critical variables affecting perfor- mance and siltation was done. Also, secondary data and a review of scientific literature were used to analyze the additional data collected and provide practical recommendations.

The study sites were selected by screening all sand storage dams in the watershed from the most upstream point to the most downstream point of the riverbeds within the boundaries of Kikumbulyu. Only 30 out of the 48 sand storage dams built in the study area were selected as study sites, as the rest had been either washed away or completed after the first data collection in 2012. The studied dams were between 1 and 52 years old. Each of the 30 study sites evaluated corresponded to the first $300 \mathrm{~m}$ of the reservoir upstream of the spillway. The first $100 \mathrm{~m}$ were divided into Section $10 \mathrm{~m}$ in length and the next $200 \mathrm{~m}$ in Section $20 \mathrm{~m}$ in length. Furthermore, all sections were divided into three subsections of equal width, i.e. left, center, and right. Thus, 60 measurements were taken from each study site. Therefore, a total of 1,800 sub-sections from 30 different reservoirs were evaluated.

\subsubsection{Sand storage capacity}

Sand storage capacity is the volume of sand sediment in the reservoirs that had the potential to store water if the actual width, 


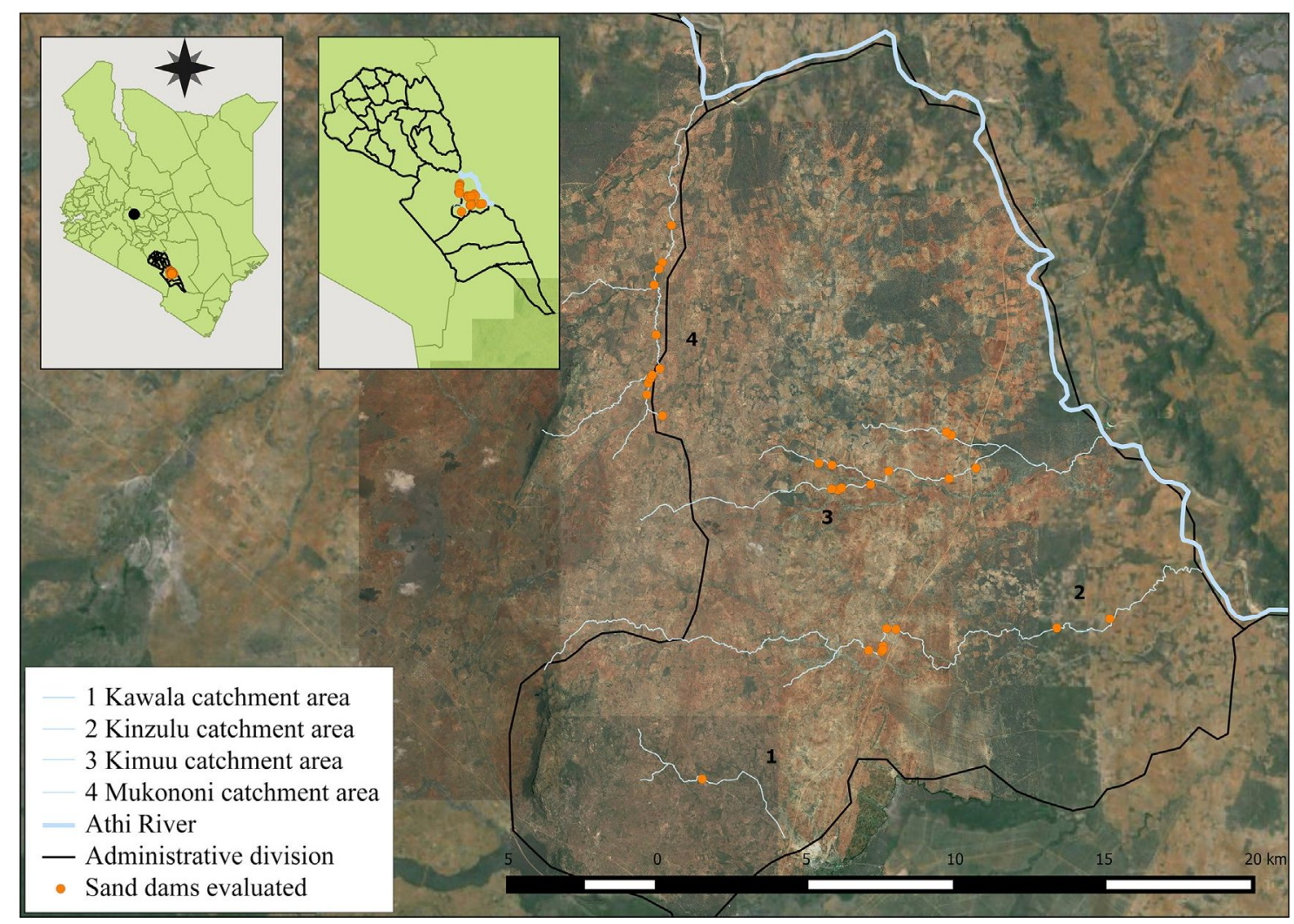

Fig. 1. Location of the study catchment areas and study sites in Kikumbulyu. The orange dots represent the sand storage dams evaluated.

depth, and length of sand sediment accumulated in each sub- section of the riverbed are considered. The depth of sand was measured at probing points by hammering an iron rod into the sand until the bedrock was found. The length of the rods was $2-4 \mathrm{~m}$, and the rods had a diameter of $14 \mathrm{~mm}$. The depth of the bed-rock did not exceed $4 \mathrm{~m}$ at any of the reservoirs evaluated.

If a layer of impermeable clayey materials greater than $0.5 \mathrm{~m}$ was found, it was assumed to mark the bottom limit of the sand reservoir with the potential to effectively supply water to local communities. This assumption is based on the fact that a well- functioning sand storage dam is an unconfined alluvial sand aquifer with primary porosity and intergranular flow. However, Heath (1987) and Morris et al. (2003) stated that the presence of strata with different hydraulic conductivities significantly affect the percolation and movement of water across the unsaturated zone, as well as the yield of an aquifer. In addition, Wheater and Al-Weshah (2002) stated that the presence of thin lenses of fine sediments within the alluvium was shown to have the potential to inhibit infiltration, as well as sub-surface redistribution. Further- more, any volume of permeable sediments beneath a layer of impermeable clayey sediments was considered to be a confined aquifer. This is consistent with Heath (1987), who stated that a confining bed is a rock unit having low hydraulic conductivity that restricts the movement of water either into or out of the reservoir. In a confined aquifer, the upper surface of the saturated zone is not free to rise and decline, and lateral flow in confining beds is usually negligible (Heath, 1987). Furthermore, Heath (1987) also stated that the storage and yield capacity of a confined aquifer is significantly lower than an unconfined aquifer. The reduced sto- rage and yield capacity of confined systems was assumed to be especially significant in the sand storage reservoirs evaluated, due to the limited volume capacity of the small-scale sand aquifer. Even though a layer of clayey materials of $0.5 \mathrm{~m}$ restricts the access to water via scoop holes in the riverbed, the sand below, if any, may still benefit the abstraction through hand-dug wells in the riverbanks in the long-term. However, the potential contribution of this layer of sand was not considered in the current study.

The sediment texture was qualitatively evaluated by direct comparison with a grain-size chart proposed by Brassington (2007). As this study did not intend to analyze the grain size of the reservoirs quantitatively, this method provided a solid basis for an accurate distinction between the different types of alluvium sediment relevant for this study: sandy, silty, or clayey alluvium soils (Brassington, 2007). Sandy sediments are relevant because their specific yield (27\%, Brassington, 2007) allows a cost-effective water yield and supply capacity. Instead, silty (8\%, Brassington, 2007) and clayey (3\%, Brassington, 2007) sediments yield low volumes of water, which do not allow a cost-effective water yield and supply capacity. Furthermore, the gradient of the first $300 \mathrm{~m}$ of each study site and the specific elevation of each probing point were measured following the principles of differential leveling using an automatic leveling device.

The formula used to analyze the sand storage capacity was based on the general equation for estimating the capacity of a water reservoir (Lawrence \& Lo Cascio, 2004; Sawunyama et al., 2006; Stephens, 2010). The formula was given by

C $1 / 4 K x D \times W \times T$

where $\mathrm{C}$ is the reservoir capacity $\left(\mathrm{m}^{3}\right), \mathrm{K}$ is a constant to reflect the geometrical shape of the reservoir, $\mathrm{D}$ and $\mathrm{W}$ are the maximum depth and width of a reservoir $(\mathrm{m})$, respectively, and $\mathrm{T}$ is the maximum length of influence of a sand storage dam, i.e., throwback (m). Eq. (1) was used to calculate the sand storage capacity of each of the 1800 sub-sections evaluated. Thus, D, W, and T were the corresponding measurements at each probing point for the depth, width, and longitude ( $\mathrm{Lg}$ ) of each sub-section. $\mathrm{K}$ was calculated from the cross-sectional profiles of each sub-section. 
$\mathrm{T}$ is found at the point where the height of the spillway intersects the original gradient of the riverbed (Forzieri et al., 2008). However, the throwback could not be calculated using this method because, during the data collection period, there had already been an accumulation of sediment behind the spillway, which modified

the original gradient of the riverbed and the real length of the influence of the sand storage dam. Therefore, $\mathrm{T}$ was assumed to be

$600 \mathrm{~m}$. This assumption may cause an overestimation of the throwback because the assumed length of influence requires low gradients, which were only present at the most downstream sites.

The total sand storage reservoir capacity $\left(\mathrm{C}_{\mathrm{T}}\right)$ of the sand storage dam is given by

\section{$\mathrm{C}_{\mathrm{T}} 1 / 4 \mathrm{C}_{\mathrm{P}} \mathbf{p C _ { \mathrm { A } }}$}

where $C_{P}$ is the sand storage capacity of the first $300 \mathrm{~m}$ that were probed, and $\mathrm{C}_{\mathrm{A}}$ is the sand storage capacity of the remaining $300 \mathrm{~m}$, which were not probed.

The formula used to calculate $\mathrm{C}_{\mathrm{P}}$ is given by

$$
C_{P} 1 / 4 \sum C_{C ; L ; R} ; C^{P} 1 / 4 C \text { p } C \text { p } \text { p }^{\mathrm{L}}
$$

where $C_{C}, C_{L}$, and $C_{R}$ were the probed reservoir capacity of the central, left, and right sub-sections $\left(\mathrm{m}^{3}\right)$, respectively (Fig. 2). To calculate $C_{C}, C_{L}$ and $C_{R}$, the specific measurements for $D, W$, Lg, and $\mathrm{K}$ at each central, left, and right subsection were substituted in Eq. (1).

The sand storage capacity of the reservoir of the non-probed section was conservatively assumed to have a proportional volume of sand to that for the probed section of the reservoir. The formula was given by

$C_{\mathrm{A}} 1 / 4 \quad \partial \mathrm{C}_{\mathrm{P}} \quad \mathrm{T}_{\mathrm{R}} \mathrm{p}=L_{\mathrm{P}}{ }^{*} K_{\mathrm{F}}$

where $T_{R}$ is the remaining length of the throwback $(m), L_{P}$ is the length of the probed section $(\mathrm{m})$, and $\mathrm{K}_{\mathrm{F}}$ is a constant with value 0.25 to take into account the progressive reduction of the reservoir capacity over distance (Lawrence \& Lo Cascio, 2004). Furthermore, $\mathrm{C}_{\mathrm{M}}$ represents the maximum volume of sand sediment that the reservoirs had the potential to accumulate if the height of the spillway and the actual width of sand sediment accumulated in each sub-section of the riverbed were con- sidered. Thus, $\mathrm{C}_{M}$ was an indication of the design and physical capacity of the reservoirs. To calculate $\mathrm{C}_{\mathrm{M}}$, D was replaced by the height of the spillway $(\mathrm{m})$ in Eq. (1). Then $C_{T}$ was re-calculated for each site.

Finally, $C_{E}$ was used to calculate the actual percentage of the volume of sand that the sand storage reservoirs was accumulating $\left(\mathrm{C}_{\mathrm{T}}\right)$, as compared to their maximum capacity to store sand sediments $\left(C_{M}\right)$. Thus, low $C_{E}$ values indicates that the reservoir is

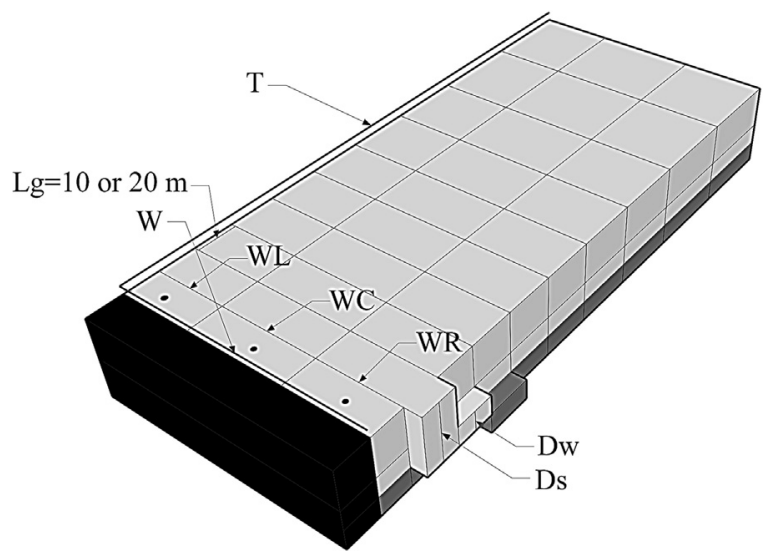

Fig. 2. Cross-sectional division of each study site indicating the central $\left(\mathrm{C}_{\mathrm{C}}\right)$, left $\left(C_{L}\right)$ and right $\left(C_{R}\right)$ sub-sections. accumulating lower volumes of sand sediment than its design and physical capacity. The formula is given by

$C_{E} 1 / 4 C_{T}=C_{M} \quad 100$

where $C_{E}$ was the sand storage efficiency (\%). Furthermore, the extent of siltation is given by:

$\mathrm{Si} 1 / 4100-C_{\mathrm{E}}$

where $\mathrm{Si}$ is the extent of siltation (\%).

\subsubsection{Specific water yield}

The specific yield of the most representative sand samples with the coarsest texture in each of the study sites was measured onthe-ground by drainage measurements from samples with a volume of sand equal to $2 \mathrm{~L}$. The first $1.0 \mathrm{~m}$ of sand was collected and left to dry out for $24 \mathrm{~h}$ by the action of the sun. Subsequently, water was poured into the sample until complete saturation. Finally, the volume of water that drained out from the saturated

sand in $12 \mathrm{~h}$ was measured. The specific water yield was calculated as follows (Brassington, 2007):

$n 1 / 4 Y_{\mathrm{S}}=V_{\mathrm{S}}$

where $\mathrm{n}$ is the specific yield (\%), $\mathrm{Y}_{\mathrm{S}}$ is the volume of drained water $(\mathrm{L})$, and $\mathrm{V}_{\mathrm{s}}$ is the volume of sand $(\mathrm{L})$.

\subsubsection{Water yield}

$\mathrm{Y}_{\mathrm{T}}$ indicates the actual capacity of the reservoirs to yield water per year, considering the volume of sand accumulated and its specific yield. The water yield is

$\mathrm{Y}_{\mathrm{T}} 1 / 4 \mathrm{C}_{\mathrm{T}} \quad \mathrm{n} \quad 2$

$ð 8 p$

where $Y_{T}$ is the annual water yield of the sand reservoir $\left(m^{3} / y\right)$ and 2 is a constant which reflects the typical bimodal rainfall season in the study area. According to Lawrence and Lo Cascio (2004), the reservoir was assumed to be full of water at the beginning of each dry season. Furthermore, $Y_{M}$ refers to the maximum annual capacity to yield water of each sand storage dam, taking into account the physical conditions of the study site (i.e. the capacity to produce sand), and the final spillway height of the dam. $Y_{M}$ is given by

$\mathrm{Y}_{\mathrm{M}} 1 / 4 \mathrm{C}_{\mathrm{M}} \quad \mathrm{n} \quad 2$

$ð 9 p$

where $C_{M}$ is the maximum annual water yield $\left(\mathrm{m}^{3} / \mathrm{y}\right)$.

\subsubsection{Water supply capacity}

$\mathrm{H}$ and $\mathrm{C}$ indicates the maximum number of households (hh) that could obtain a continuous water supply that was sufficient to meet their needs during the entire hot $(\mathrm{H})$ and cold $(\mathrm{C})$ dry sea- sons, respectively. Thus, $\mathrm{H}$ and $\mathrm{C}$ depend on the water yield of the sand reservoir and the water needs of the beneficiaries. $\mathrm{H}$ and $\mathrm{C}$ can be estimated as follows:

$H ; C 1 / 4 Y_{h ; c}=C_{\mathrm{OT}}$

where $\mathrm{H}, \mathrm{C}$ is the total number of households supplied by the sand storage dam during the hot and cold dry seasons, respectively (hh), $\mathrm{Y}_{h, \mathrm{c}}$ was the water yield during the hot $\left(\mathrm{Y}_{h}\right)$ and cold $\left(\mathrm{Y}_{\mathrm{c}}\right)$ dry seasons $\left(\mathrm{m}^{3}\right)$, and Сот is the water need per household during the entire dry season $\left(\mathrm{m}^{3}\right)$. Сот is estimated as follows:

Cот $1 / 4 \mathrm{CoH} \quad \mathrm{DH} ; \mathrm{C}$

where $\mathrm{COH}_{\mathrm{OH}}$ is the total consumption of one household per day $\left(\mathrm{m}^{3} / \mathrm{d}\right)$, and $\mathrm{D}_{\mathrm{H}, \mathrm{C}}$ is the length of the hot and cold dry seasons, respectively $(\mathrm{d})$.

$\mathrm{C}_{\mathrm{OH}}$ for one household of 5 persons (GoK, 2009a) was estimated to be $280 \mathrm{~L} / \mathrm{hh} \cdot \mathrm{d}$, which is equivalent to 14 jerry cans of $20 \mathrm{~L}$. This value is equivalent to $25 \mathrm{~m}^{3} / \mathrm{hh}$ for the typical 3-month hot dry season (GoK, 2012a), and $42 \mathrm{~m}^{3} / \mathrm{hh}$ for the typical 5-month cold 
dry season (GoK, 2012b). The water requirements used in this study were consistent with the water needs of the beneficiaries interviewed in the study area for domestic, livestock, and off- season microirrigation uses. In addition, the water requirements were consistent with the minimum needs per capita to satisfac- torily meet domestic, livestock, and off-season micro-scale irriga- tion needs, according to Okun and Ernst (1987), World Health Organization (WHO) (2005), and GoK (2009b). The water requirements used in this study were conservative, as they were lower than $135 \mathrm{~L} / \mathrm{c} / \mathrm{d}$, which is recommended as the minimum for human health, and economic and social development by Cheno- weth (2008).

\subsubsection{Evaporation and seepage losses}

Evaporation losses were not measured, but calculated by subtracting a constant value of $0.6 \mathrm{~m}$ from the measured depth of sand of each probing section. This value, which was used to determine the potential storage below the evaporation line, was obtained from Hellwig (1973). Thus, $D_{E}$ is estimated as follows:

$D_{E} 1 / 4 D-0: 6$

where $\mathrm{D}_{\mathrm{E}}$ is the depth of sand sediment which were not affected

by evaporation (m), D is the depth of sand (m), and 0.6 is a con- stant reflecting the evaporation losses $(\mathrm{m})$.

The $D_{E}$ used in this study may be a conservative value, because $0.6 \mathrm{~m}$ is the evaporation depth for coarse sand sediments (Hellwig, 1973). However, $D_{\mathrm{E}}$ may be higher for reservoirs with finer grainsize sediment. In addition, Hellwig (1973) found that evaporation reduced to approximately $10 \%$ when the water table was at $0.6 \mathrm{~m}$ below the surface of coarse sandy alluvium sediment but actually stopped at $0.9-1.0 \mathrm{~m}$. This is in line with Wipplinger (1958), who found that $D_{E}$ was $0.9 \mathrm{~m}$ in a multi-year study in different sand storage dams collecting medium and fine sand sediments. Taking into account $\mathrm{D}_{\mathrm{E}}$, the water yield and supply capacity after considering evaporation losses $\left(\mathrm{Y}_{\mathrm{E}}, \mathrm{m}^{3} ; \mathrm{H}_{\mathrm{hE}}, \mathrm{H}_{\mathrm{CE}}, \mathrm{hh}\right)$ was re-calculated by replacing $\mathrm{D}$ by $\mathrm{D}_{\mathrm{E}}$ in Eq. (1).

Seepage losses were taken into account by using $5 \%$ as a

representative percentage of the total water yield which may be lost by seepage in a sand storage dam (Lasage et al., 2015). Considering this value, the formula to calculate the yield after eva-

poration and seepage losses is given by

$\mathrm{Y}_{\mathrm{S}} 1 / 4 \mathrm{Y}_{\mathrm{E}} \times 0: 95$

where $Y_{S}$ is the yield after taking into account seepage and evaporation losses $\left(\mathrm{m}^{3}\right)$, and 0.95 is a constant to account for seepage losses.

Taking into account $\mathrm{Y}_{\mathrm{S}}$, the water supply capacity after considering seepage losses $\left(\mathrm{H}_{\mathrm{s}}, \mathrm{C}_{\mathrm{S}}, \mathrm{hh}\right)$ was re-calculated.

\subsubsection{Contribution from the riverbanks}

A potential contribution from the riverbanks was taken as a constant value of 1.58. This value was calculated using data from Borst and De Haas (2006), who did a study on the hydrogeology of a successful sand storage dam in southeastern Kenya. The formula is given by

$\mathrm{Y}_{\mathrm{R}} 1 / 4 \mathrm{Y}_{\mathrm{S}} \times 1: 58$

$ð 14 \mathrm{p}$

where $Y_{R}$ is the yield after accounting for seepage, evaporation losses, and a contribution from the riverbanks $\left(\mathrm{m}^{3}\right)$, and 1.58 is a constant to account for a potential contribution from the riverbanks. After obtaining $\mathrm{Y}_{\mathrm{R}}$, the water supply capacity considering a potential contribution from the riverbanks $\left(\mathrm{H}_{R}, \mathrm{C}_{\mathrm{R}}, \mathrm{hh}\right)$ was recalculated.

\subsubsection{Construction costs}

The capital construction costs (CC) were based on the structural estimating the fill volume (Jaafar, 2014). The price of the construction materials was, in all the cases, the value in Kenyan Shillings for 2012, which was then converted to U.S. dollars (USD) with the annual average conversion value for 2012. The costs for a contractor per each sand storage dam implemented (162 USD/sand storage $\mathrm{dam})$ and $15 \%$ indirect costs were included in the calcu- lations. The community contribution was not included, as it is usually provided on a no-cost basis (Lasage \& Verburg, 2015). As a result of this, the total cost to build rubble stone masonry without shuttering was estimated to be $154 \mathrm{USD} / \mathrm{m}^{3}$ of the dam. The values for the reinforced rubble stone masonry with timber shuttering were 298 $\mathrm{USD} / \mathrm{m}^{3}$ of the dam.

$\mathrm{AC}$ is the uniform annual cost of owning and operating a sand storage dam over a specific time period. As proposed by Jaafar (2014), the formula to estimate the annual costs is given by

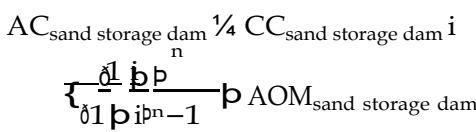

where AC is the annualized cost (USD/y), CC is the capital cost of the sand storage dam (USD), $\mathrm{i}$ is the interest rate (\%) (5\%, Jaafar, 2014), $\mathrm{n}$ is the lifespan of the sand storage dam (y) (20 y, Batchelor et al., 2011), and AOM is the annual operation and maintenance cost (USD) (0 USD, Lasage \& Verburg, 2015).

\subsubsection{Cost-efficiency}

Cost-efficiency is meant to measure the technical efficiency of the sand storage dams as the cost of $1 \mathrm{~m}^{3}$ of water yielded by the sand storage dams (cost-efficiency for the water yield) and the cost of supplying one household during the entire dry season (cost-efficiency of the water supply capacity). The formulas for the cost-efficiency are as follows:

$$
\begin{aligned}
& \text { CC sand storage dam ðUSDP } \\
& \text { CE } 1 / 4 \text { Water Yield }\left(\mathrm{m}^{3}\right) \text { or Water Supply ðhhp } \\
& \mathrm{ACE}^{1 / 4} \frac{\mathrm{AC} \text { sand storage dam }}{\text { Water Yield }\left(\mathrm{m}^{3}{ }^{\mathrm{d}} \mathrm{SD}=\mathrm{y}\right.} \underline{\mathrm{p} \text { or Water Supply }{ }^{\gamma \mathrm{hhp}}}
\end{aligned}
$$$$
ð 16
$$

measurements of the sand storage dams, and were obtained by 
where $\mathrm{CE}$ is the capital cost-efficiency of the annual water yield $\left(\mathrm{USD} / \mathrm{m}^{3}\right.$ ) or supply capacity (USD/household), and ACE is the annualized cost-efficiency of the annual water yield $\left(\mathrm{USD} / \mathrm{m}^{3} \cdot \mathrm{y}\right.$ ) or supply capacity $(\mathrm{USD} / \mathrm{hh} \cdot \mathrm{y})$.

\subsubsection{Normalization}

All the variables associated with the performance were normalized by considering the volume of construction $\left(\mathrm{m}^{3}\right)$ used to build the sand storage dams. The normalization allows future comparison with data from prospective evaluations in other arid and semi-arid areas.

\subsubsection{Sensitivity analysis}

The robustness of the results to the throwback length (assumed); the specific yield and geometrical shape (measured); and the evaporation depth, seepage, contribution from the riverbanks, household size, the length of the dry season, and the water consumption (secondary data) was tested using sensitivity analysis. The sensitivity analysis was done taking into account the impact on the total number of households supplied for all 30 sand storage dams during the 3-month hot dry season. 


\section{Results}

\subsection{Sand storage capacity}

Most reservoirs had low average and median volumes of sandsize particles (Table 1). Furthermore, generalized low values of sand storage efficiency indicated that large volumes of fine grain- size sediment, namely silty and clayey alluvium sediment, had accumulated in combination with any coarse material transported by the flood, leading to low values of sand storage efficiency.

Even though the presence of fine grain-size alluvium sediment was higher than sandy alluvium sediment in 20 reservoirs out of the total of 30, sand sediment was identified in 26 reservoirs. Furthermore, reservoirs showing high and medium values of sand were found throughout the study area in the different watersheds evaluated. Also, only 4 sand storage dams had a total absence of sand sediment in the reservoirs. The individual sand storage capacity of the sand storage dams can be found in the supplementary.

\subsection{Water yield capacity}

The measured specific yield of the samples from the reservoirs was low, with an average value of $7 \%$, and 24 reservoirs did not contain water at the time of the data collection. It was reported by the beneficiaries interviewed that these reservoirs did not yield water from the alluvium sediment, but that they accumulated surface water for up to $2-4$ months after the rainy season.

Table 2 lists the annual and maximum annual water yield capacity of the study area. The water yield after considering potential evaporation and seepage losses, and after considering these losses and a potential contribution from the riverbanks also were considered. The maximum water yield was higher than the annual water yield, which indicated that the reservoirs yielded lower volumes of water than the physical capacity of the study site. Furthermore, estimated evaporation and seepage losses cor-respond to $48 \%$ of the total volume produced by all sand storage dams in the study area. The losses reduced to $23 \%$ after assuming an increase in the water yield if a potential contribution from the riverbanks was considered. The individual water yield capacity of the sand storage dams can be found in the supplementary materials.

\subsection{Water supply capacity}

Table 3 lists the actual and maximum number of households that all sand storage dams had the capacity to supply in the study area. Evaporation and seepage losses, and a contribution from the riverbanks were also considered.

Twenty reservoirs could not yield sufficient water to supply one household throughout any of the two dry seasons. The max-imum supply capacity of most sand storage dams also was low. All sand storage dams had lower supply capacities if potential eva- poration and seepage losses were taken into account. The results did not improve after accounting for a potential contribution from the riverbanks. The individual water supply capacity of the sand storage dams can be found in the supplementary materials.

\subsection{Capital and annualized costs}

Table 4 lists the typical dimensions, the volume of construction, and the capital and annualized costs in the study area. The average capital construction cost of the 30 sand storage dams evaluated was 11,000 USD. Furthermore, all sand storage dams were built in onestage with an average height of $3.1 \mathrm{~m}$. The individual con- struction costs of the sand storage dams can be found in the supplementary materials.

\subsection{Cost-efficiency}

There was a strong predominance of low annualized cost-efficiency levels for the annual water yield and supply capacity. If potential evaporation and seepage losses were considered, the sand storage dams would show lower average capital and annualized cost-efficiencies. A potential contribution from the riverbanks after considering evaporation and seepage losses did not reduce the cost to produce $1 \mathrm{~m}^{3}$ of water or to supply one household during the entire dry season. For the maximum yearly yield, the cost-efficiencies for all sand storage dams increased by an average factor of 24 . For the maximum supply capacity, the average increase factor was 5 . The total investment for all sand storage dams yielding less than $1 \mathrm{~m}^{3}$ was 54,000 USD. As an average between the hot and cold dry season, 220,000 USD were invested in sand storage dams which were not able to supply one household during the entire dry season. The cost-efficiency of the individual sand storage dams can be found in the supplementary materials.

Table 1

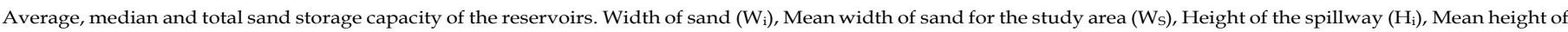

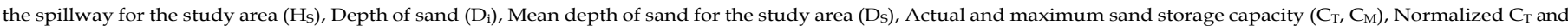
$\mathrm{C}_{\mathrm{M}}\left(\mathrm{C}_{\mathrm{TN}}, \mathrm{C}_{\mathrm{MN}}\right)\left(\mathrm{m}^{3}\right.$ sand $/ \mathrm{m}^{3}$ construction), Sand storage efficiency $\left(\mathrm{C}_{\mathrm{E}}\right)$, Siltation (Si), Minimum (min), Maximum (max), Standard deviation (Std. dev).

\begin{tabular}{|c|c|c|c|c|c|c|c|c|c|c|c|c|}
\hline & $W_{i}$ & Ws (m) & $\mathrm{Hi}_{\mathrm{i}}(\mathrm{m})$ & $\mathrm{Hs}(\mathrm{m})$ & $D_{i}(m)$ & Ds (m) & $C_{T S}\left(m^{3}\right)$ & $\mathrm{C}_{\mathrm{TN}}$ & $C_{M}\left(m^{3}\right)$ & $C_{M N}$ & CE (\%) & Si (\%) \\
\hline$[\min , \max ]$ & {$[0.0,49.4]$} & {$[1.9,11.6]$} & {$[1.3,5.3]$} & & {$[0.0,3.0]$} & {$[0.1,0.9]$} & {$[0,7166]$} & & & & & \\
\hline Average (Std. dev) & & $5.3(4.4)$ & & 3.1 & & $0.3(0.3)$ & 782 & 21 & 3157 & 102 & 18 & 82 \\
\hline Median [min, max] & & $5.2[0.9,11.7]$ & & 3.2 & & $0.1[0.0,0.7]$ & 116 & 3 & 1729 & 68 & 8 & 92 \\
\hline Total & & & & & & & 23,452 & & 94,704 & & & \\
\hline
\end{tabular}

Table 2

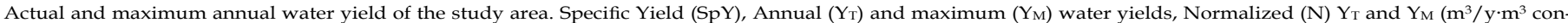

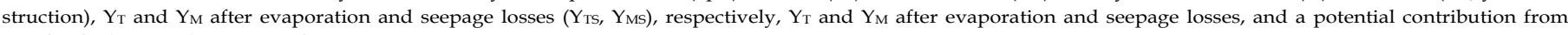
riverbanks $\left(\mathrm{Y}_{\mathrm{TR}}, \mathrm{Y}_{\mathrm{MR}}\right)$, respectively.

\begin{tabular}{|c|c|c|c|c|c|c|c|c|c|}
\hline & SpY (\%) & $Y_{T}\left(m^{3} / y\right)$ & $\mathrm{NY}_{\mathrm{T}}$ & $\mathrm{Y}_{\mathrm{TS}}\left(\mathrm{m}^{3} / \mathrm{y}\right)$ & $Y_{T R}\left(m^{3} / y\right)$ & $Y_{M}\left(m^{3} / y\right)$ & $N Y_{M}$ & $Y_{M S}\left(m^{3} / y\right)$ & $Y_{M R}\left(m^{3} / y\right)$ \\
\hline Average & 7.2 & 112.3 & 3.0 & 55.2 & 87.2 & 459.8 & 14.4 & 338.9 & 535.4 \\
\hline Median & 6.9 & 15.8 & 0.4 & 0.0 & 0.0 & 247.7 & 9.1 & 112.4 & 177.6 \\
\hline Total & & 3368 & & 1656 & 2617 & 13,795 & & 10,166 & 16,062 \\
\hline
\end{tabular}


Table 3

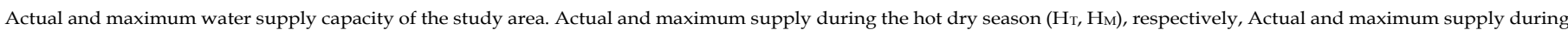

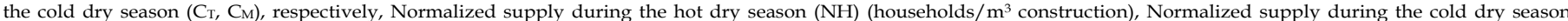

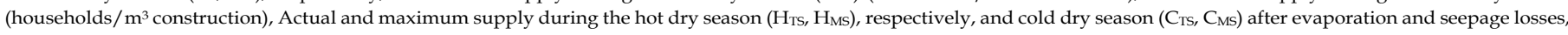

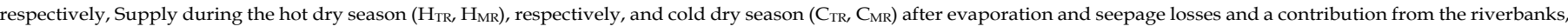
respectively.

\begin{tabular}{|c|c|c|c|c|c|c|c|c|c|c|c|c|c|c|c|c|}
\hline & \multicolumn{8}{|c|}{ Actual water supply capacity (households) } & \multicolumn{8}{|c|}{ Maximum water supply capacity (households) } \\
\hline & $\mathrm{H}_{\mathrm{T}}$ & $\mathrm{C}_{\mathrm{T}}$ & $\mathrm{NH}_{\mathrm{T}}$ & $\mathrm{NC}_{\mathrm{T}}$ & $\mathrm{H}_{\mathrm{TS}}$ & $\mathrm{C}_{\mathrm{TS}}$ & $\mathrm{H}_{\mathrm{TR}}$ & $\mathrm{C}_{\mathrm{TR}}$ & $\mathrm{H}_{\mathrm{M}}$ & $\mathrm{C}_{\mathrm{M}}$ & $\mathrm{NH}_{\mathrm{M}}$ & $\mathrm{NC}_{\mathrm{M}}$ & $\mathrm{H}_{\mathrm{MA}}$ & $\mathrm{C}_{\mathrm{MS}}$ & $\mathrm{H}_{\mathrm{MR}}$ & $\mathrm{C}_{\mathrm{MR}}$ \\
\hline Average & 0 & 0 & 0 & 0 & 0 & 0 & 0 & 0 & 9 & 5 & 0 & 0 & 7 & 4 & 11 & 6 \\
\hline Median & 2 & 1 & 0 & 0 & 1 & 1 & 2 & 1 & 5 & 3 & 0 & 0 & 2 & 1 & 4 & 2 \\
\hline Total & 66 & 40 & & & 33 & 19 & 52 & 31 & 272 & 163 & & & 201 & 120 & 317 & 190 \\
\hline Total (people) & 330 & 200 & & & 165 & 95 & 258 & 155 & 1362 & 817 & & & 1003 & 602 & 1585 & 951 \\
\hline
\end{tabular}

Table 4

Costs, dimensions, and volume of construction. Height of the spillway $(\mathrm{H})$, Width of the dam (W), Length of the dam (L), Volume of construction (V), Capital Costs (CC), Annualized costs (AC), minimum (min), maximum (max).

$$
\begin{aligned}
& H(m) W \text { mean }\left[\min , \quad L(m) \vee\left(m^{3}\right) C C(U S D) A C\right. \text { (USD/y) } \\
& \text { max] }
\end{aligned}
$$

\begin{tabular}{lllllll} 
Average & 3.1 & $0.6[0.4,0.7]$ & 27.4 & 39 & 10,856 & 871 \\
Median & 3.2 & $0.6[0.4,0.7]$ & 25.5 & 32 & 9232 & 741 \\
Total & & & & 1091 & 303,973 & 24,392 \\
\hline
\end{tabular}

\subsection{Classificati on of the perfor ance and cos-efficiency of the sand}

reservoirs

Based on an analysis of relevant scientific literature (Batchelor et al., 2011; Borst \& De Haas, 2006; Knoop et al., 2012; Lasage \& Verburg, 2015; Nissen-Petersen, 2006; Studer \& Liniger, 2013; Tuinhof et al., 2012), the actual performance and cost-efficiency of the sand storage dams evaluated was classified according to pre- viously reported satisfactory values of water yield, supply capacity, and costefficiency. Thus, Table 5 shows that most of the sand storage dams evaluated performed poorly, both in regard to their technical optimum, as well as meeting local community needs. The low performance was caused by generalized low sand storage capacities and low specific yields of the sediment accumulated in the reservoir, which in turn caused generalized low annual yields, reduced supply capacities, and low cost-efficiency. The low per-formance was in line with the limited positive impacts reported by local communities in 2012 and 2015.

\subsection{Sensitivity analysis}

The only value which was assumed in this study was the throwback $(600 \mathrm{~m})$. However, this variable showed the lowest sensitivity associated with an increase in the water supply capacity up to 1.2 times with a value of $900 \mathrm{~m}$ (Fig. 3a). Due to the low sensitivity to changes in the throwback, the assumed value for the throwback did not affect the results of this study.

The household size was taken from national surveys (GoK, 2009a). Changes in this variable showed a sensitivity associated with an increase in the total water supply capacity for the whole study area up to 1.6 times with a household size of 3 people per household. In addition, seepage losses were considered under the premise that all water reservoirs are affected by seepage (Stephens, 2010). Changes in this variable showed a sensitivity associated with a decrease in the total water supply capacity for the whole study area up to 1.8 times with seepage losses of $50 \%$ of the total water yield (Fig. 3b). The value for the seepage losses used in this study (5\%, Lasage et al., 2015) may underestimate the seepage losses in the study area because several of the sand reservoirs with a satisfactory sand storage capacity presented clear signs of
Table 5

Number of sand storage dams classified according to their sand storage capacity, water yield and supply capacity, and cost-efficiency. Actual $\left(\mathrm{IC}_{\mathrm{T}}\right)$ and maximum $\left(\mathrm{IC}_{\mathrm{M}}\right)$ sand storage capacity index: $\mathrm{L} 1 / 4$ Low $\left(\mathrm{C}_{\mathrm{T}} \mathrm{O} 3000 \mathrm{~m}^{3}\right), \mathrm{M} 1 / 4 \mathrm{Medium}(3000$ $\left.\mathrm{m}^{3} 4 \mathrm{C}_{\mathrm{T}} \mathrm{O} 6000 \mathrm{~m}^{3}\right), \mathrm{H}$ 1/4 High (CT $\left.46000 \mathrm{~m}^{3}\right)$; Annual (IYT) and maximum (IYM) water yield index: $\mathrm{H} 1 / 4 \mathrm{High}\left(\mathrm{Y} 42000 \mathrm{~m}^{3} / \mathrm{y}\right), \mathrm{M}$ 1/4 Medium $\left(1000 \mathrm{~m}^{3} / \mathrm{y}\right.$ o Y 4 $2000 \mathrm{~m}^{3} / \mathrm{y}$ ), L $1 / 4$ Low (Y O $1000 \mathrm{~m}^{3} / \mathrm{y}$ ); Actual (IST) and maximum (IS $\mathrm{IS}_{\mathrm{T}}$ ) supply

capacity inaex: L \%/4 LOW (IST $\mathbf{r}<0$ nousenolas (nn)), IVI \%/4 IVledium (OU nn $<$ is 4 $25 \mathrm{hh}$ ), H 1/4 High (IS $450 \mathrm{hh}$ ); Actual (IACE ) and Maximum (IACE $\mathrm{M}$ ) annualized cost-efficiency index: $\mathrm{H} 1 / 4$ High (ACE O 0.4 USD), M 1/4 Medium (1.1 USD 4 ACE 40.4 USD), L 1/4 Low (ACE 41.1 USD), Annualized cost-efficiency index for the actual (IALEST) ana maximum (IACESM) suppiy capacity: H \% Hign (ALES O 10 USD/hh·y), M 1/4 Medium (35 USD/hh·y O ACES 418 USD/hh·y), L 1/4 Low (ACES 4 35 USD/hh·y).

\begin{tabular}{llllll}
\hline & ICT & IYT & IST & IACET & IACEST \\
\hline Low & 28 & 29 & 30 & 30 & 30 \\
Moderate & 0 & 1 & 0 & 0 & 0 \\
High & 2 & 0 & 0 & 0 & 0 \\
& IC & IYM & ISM & IACEM & IACESM \\
Low & 21 & 23 & 28 & 23 & 28 \\
Moderate & 3 & 5 & 0 & 5 & 1 \\
High & 6 & 2 & 2 & 2 & 1 \\
\hline
\end{tabular}

seepage. In addition, the evaporation depth had sensitivities associated with a decrease in the total water supply capacity for up to 2.8 times the whole study area with a value of $90 \mathrm{~cm}$ (Fig. 3c). The evaporation depth $(0.6 \mathrm{~m})$ was taken from multi-year studies focusing on the evaporation of water from coarse sand sediments (Hellwig, 1973) and from sand storage dams (Wipplinger, 1958) with coarser sand sediments than the sand reservoirs evaluated. Therefore, the evaporation depth used in this study may underestimate the real-life evaporation losses of the reservoirs, because fine grain sediment presents higher evaporation depths (Helweg \& Smith, 1978). However, a continuous draw-off may lower the water level in the sand reservoir below $0.6 \mathrm{~m}$ before the water stored above this evaporation depth is evaporated. In this case, the evaporation depth used in this study may overestimate potential evaporation losses in sand storage reservoirs. This is in line with Wipplinger (1958), who found that with no draw-off, evaporation losses can cause a drop in the water level of $0.9 \mathrm{~m}$ in three months. The sensitivity analysis showed that evaporation depths of 30 and $15 \mathrm{~cm}$ would result in an increase in the total supply capacity for the whole study area up to 1.4 and 1.6 times, respectively. For the evaporation and seepage losses, the low values of yield and supply without considering these losses (Tables 2 and 3), and the generalized low access of water from the alluvium sediment (Section 3.2 ), indicate that the evaporation and seepage losses in this study did not affect the robustness of the results. For further studies, it is recommended to measure evaporation and seepage losses during the entire dry season. 


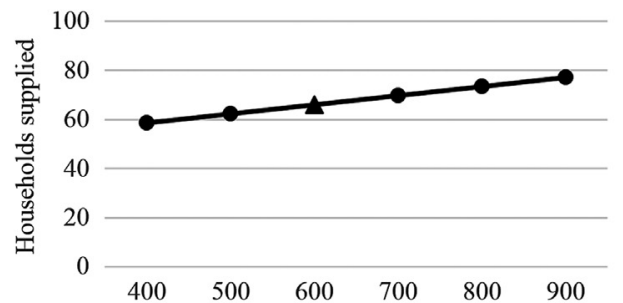

(a) Throwback (m)

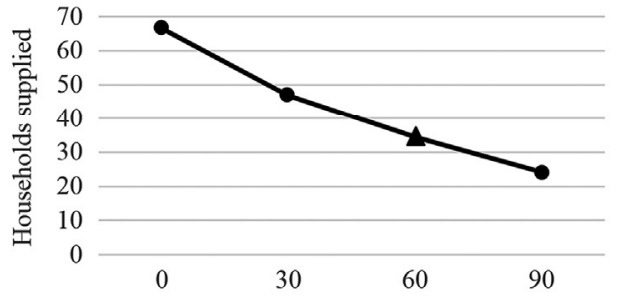

(c) Evaporation depth (cm)

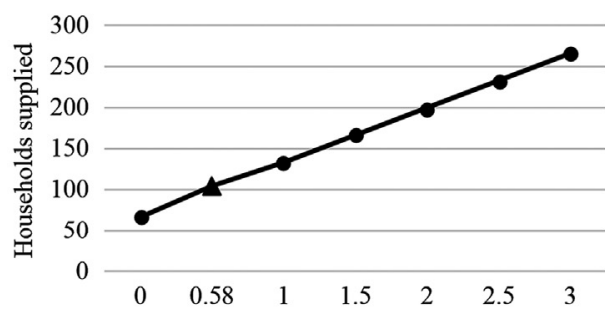

(e) Contribution riverbanks (\%)

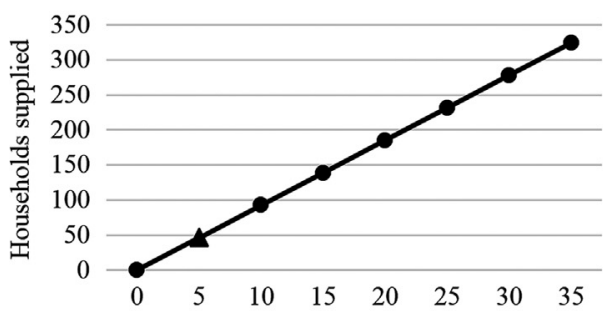

(g) Specific yield (\%)

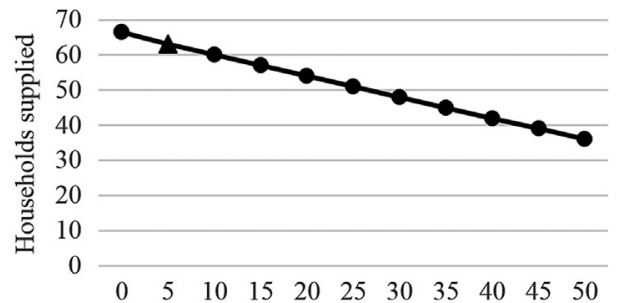

(b) Seepage (\%)

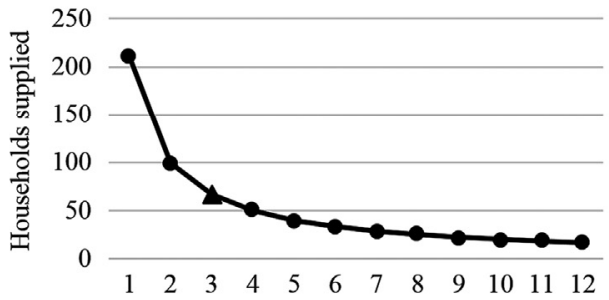

(d) Length dry season (months)

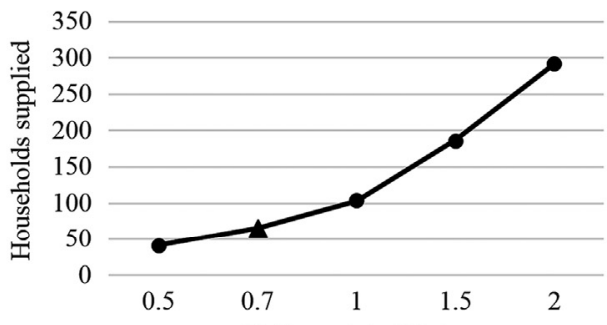

(f) Geometrical factor

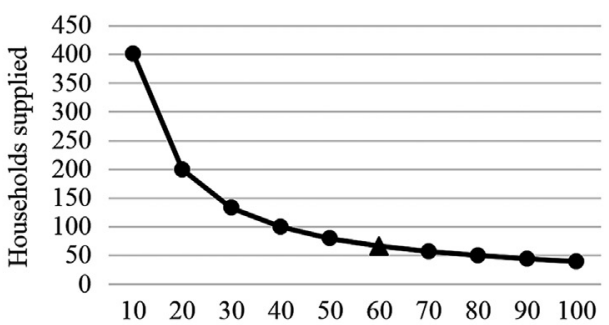

(h) Water consumption (L/c/d)

Fig. 3. Sensitivity analysis for the variables which were assumed (a) or taken from secondary data (b-h). The triangular markers show the values used in this study.

The length of the dry season had sensitivities associated with an increase in the total water supplycapacity for the entire study area up to 3.2 times with a value of 1 month (Fig. 3d). However, the length of the dry season was taken from ex-post assessments of the rainfall distribution concerning the study area during the evaluation period (GoK, 2012a, 2012b). Therefore, the length of the dry season used in this study was representative of the study area. In addition, changes in the contribution from the riverbanks had sensitivities associated with an increase in the total water supply capacity for the entire study area up to 4 times with a constant for the contribution of the riverbanks equal to 3 (Fig. 3e). The contribution of the riverbanks was calculated using secondary data (Borst \& De Haas, 2006). Even though the results are sensitive to the contribution from the riverbanks, such contribution is only to be expected when the riverbanks are formed by permeable materials. As the riverbanks of the study sites were predominantly formed by silty and clayey sediments, the contribution of the riverbanks was negligible. Therefore, the sensitivity of this variable did not affect the robustness of the results. For further studies, it is recommended to make an on-the-ground evaluation of a potential contribution from the riverbanks if the riverbanks are formed by permeable materials. Furthermore, changes in the geometrical shape had sensitivities associated with an increase in the total water supply capacity up to 4.4 times with a geometrical factor equal to 2 (Fig. 3f). As the geometrical shape was calculated from 3 sand depth measurements along the width of the riverbank at each probing section, the sensitivity of this variable did not affect the results of this study.

The results were also sensitive to changes in the specific yield of the sediment accumulated in the reservoir, with an increase up to 4.9 times using the maximum specific yield associated with coarse sand sediment (35\%) (Johnson, 1967) (Fig. 3g). The increase is consistent with the expected higher yield associated with coarse sand sediment. However, the specific yield used in this study was measured, and, therefore, the sensitivity of this variable did not affect the accuracy and robustness of the results. In addition, the results were sensitive to changes in the water consumption, which had an impact on the water supply capacity up to an increase of 6.1 times with a water consumption of $10 \mathrm{~L} / \mathrm{c} / \mathrm{d}$ (Fig. 3h). The water consumption used in this study $(56 \mathrm{~L} / \mathrm{c} / \mathrm{d})$ was in line with the minimum $60 \mathrm{~L} / \mathrm{c} / \mathrm{d}$ proposed by World Health Organization (WHO) (2005) to cover strictly domestic needs and water to grow food at the household level. In addition, the total daily water consumption per household $(\mathrm{L} / \mathrm{d} / \mathrm{hh})$ proposed in this study $(280 \mathrm{~L} / \mathrm{d} / \mathrm{hh})$ was 
lower than 531 L/d/hh, which was obtained by Lasage et al. (2008) for households using sand storage dams and engaging in irrigated agriculture without considering livestock water needs. Whereas lower water consumption needs would increase the water supply capacity of the sand storage dams evaluated, the water supplied by the sand storage dams would not be sufficient to cover the minimum needs to bring significant economic and social development to the beneficiaries (Chenoweth, 2008; World Health Organization (WHO), 2005).

All the sensitivity functions had a tendency to be linear, except for the water consumption and the length of the dry season. In these two cases, there was a steep decrease in the water supply capacity for values greater than $20 \mathrm{~L} / \mathrm{c} / \mathrm{d}$ (water consumption) and 2 months (length of the dry season). $20 \mathrm{~L} / \mathrm{c} / \mathrm{d}$ are insufficient to bring a positive impact to local communities in the study area, as it is lower than the minimum amount required to cover domestic needs and water to grow food at the household level (World Health Organization (WHO), 2005) and for satisfactory economic and social development (Chenoweth, 2008). Also, the usual minimum length of the dry season in the study area is 3 months (GoK, 2012a). Therefore, the steep decrease in the water supply capacity after 2 months indicates a low robustness to the regular length of dry periods, which will worsen during poor rainfall years and droughts.

\section{Discussion}

\subsection{Factors leading to siltation and poor performance}

\subsubsection{Inter- and intra-annual bedload transport variability coupled} with one-stage spillways

Alexandrov et al. (2009) and Cantalice et al. (2013) showed that rainfall, runoff, and sediment transport in arid and semi-arid regions are highly variable, both for individual storms, as well as for seasonal and annual totals. Furthermore, Reid and Frostick (2011) found that runoff generally consisted of fine grain-size sediment during the last stages of flood flows. In addition, bedload transport frequently accounts for a minimum portion of the sediment transported in the runoff in arid and semi-arid environments (Alexandrov et al., 2009). Alexandrov et al. (2009) also proved that bedload transport depended on a well-defined entrainment threshold. Thus, these authors highlighted that when flows did not reach the bedload entrainment threshold, the bedload yield tended to be zero, which happened in at least $30 \%$ of the runoff events evaluated in a 15-year study (Alexandrov et al., 2009). Thus, low-intensity events may produce bedload layer heights which are very low or non-existent (Alexandrov et al., 2009). In addition, at least $40-60 \%$ of the years, on a decadal scale, are poor rainfall years in arid and semi-arid areas (Gichuki, 2000), which may increase the frequency of low bedload transport rates (Wipplinger, 1958). This historic variability is to be coupled with the clear trend towards increased variability of rainfall events in subSaharan Africa (Pachauri et al., 2014), which may exacerbate the variability of the bedload layer height. Also, Wipplinger (1958) proved that the height of the spillway reduced the energy avail- able for sediment transport, and, therefore, facilitated the accu- mulation of fine grain-size sediment in the reservoir. Due to these facts, it is argued that the primary driving factor that caused sil- tation and the associated poor performance of the evaluated sand storage dams was the inherent high variability of the bedload transport at an interand intra-annual level. This variability, cou- pled with the construction of one-stage spillways, led to the accumulation of large volumes of fine grain-size sediment trans- ported as part of the suspended load during runoff events with bedload layer heights lower than the height of the one-stage spillways.

\subsubsection{Height of the spillway}

Fig. 4 shows a correlation analysis between the spillway height and the extent of siltation of the sand storage dams evaluated, and between the spillway height and the annual water yield. In both cases, the correlation was low, which indicated that there were other variables which led to siltation and poor performance levels. As only the sites which had a satisfactory capacity to produce sand sediment were used for the correlation analysis (Table 6), the capacity to produce sand sediment, which is inherently related to an inadequate siting procedure, did not exert any significant influence. Also, potential evaporation and seepage losses, and a contribution from the riverbanks were not considered in the cor- relation analysis, because only the annual yield without con- sidering these variables $\left(\mathrm{Y}_{\mathrm{T}}\right.$, Section 2.2.3) was used. Thus, these variables did not influence the correlation analysis. Therefore, it is argued that the low correlation values and the existence of another variable responsible for the siltation and performance were consistent with the influence of the variability of the bedload transport on the performance of onestage sand storage dams, as has been previously discussed. Thus, as the bedload transport is highly variable both inter- and intraannually, and usually corre- sponds to a minority of the total sediment load, bedload transport rates lower than the height of the one-stage spillway during individual storms and for seasonal and annual totals may lead to the accumulation of large volumes of fine grain sediment trans- ported as part of the suspended load. This may explain why most of the one-stage sand storage dams in the study area were largely affected by siltation and showed low annual yields.

In addition, these same variable bedload transport conditions also dictate that during less frequent high bedload transport rate conditions, low volumes of fine grain sediment transported as part of the suspended load can be trapped behind the spillway. This may explain why there were several sand storage dams accumu- lating satisfactory volumes of sand sediment in the study area. Furthermore, the low correlation results were also consistent with the fact that all sand storage dams evaluated had high spillway
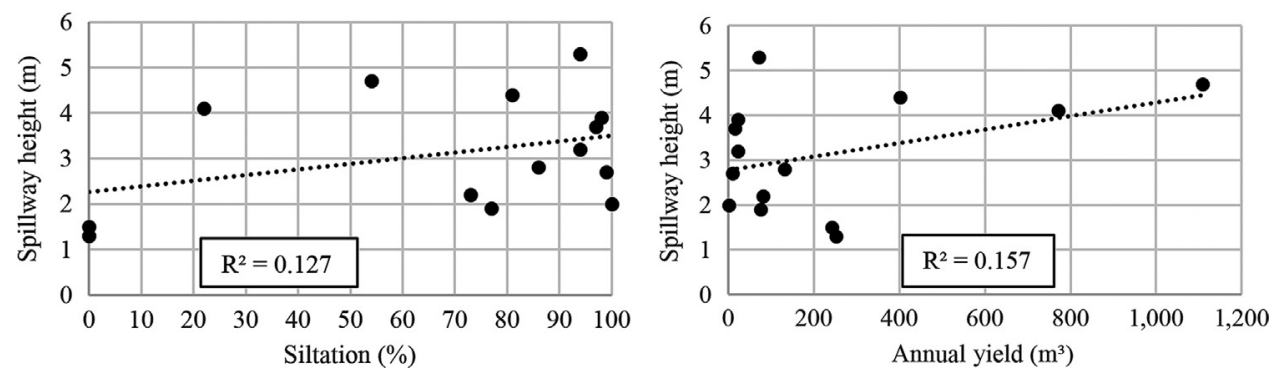

Fig. 4. Correlation analysis between the spillway height and the extent of siltation (left), and between the spillway height and the annual yield (right). Sample size: 14 (2 sites with a satisfactory capacity to produce sand sediment were not included because the spillways were severely damaged). 
heights ( $40.6 \mathrm{~m}$, De Trincheria et al., 2016) built in one stage. Therefore, the spillway heights used in the study area may be too high to show a strong correlation with the extent of siltation and the performance because most of the spillway heights evaluated were high enough to accumulate large volumes of fine grain sediment transported as suspended load during regular bedload transport rates.

Fig. 5 shows the magnitude of the bedload transport variability and its influence on the stage height. The bedload depth of 5 different runoff events for a gravel-bed ephemeral stream in the Negev Desert was measured by Reid et al. (1995). The measure- ments show that the bedload transport was variable between different runoff events and during the same runoff event. With regard to the influence on the stage height and the extent of sil- tation, it may be deduced that a sand storage dam with a spillway height of $1 \mathrm{~m}$ would have accumulated $40 \%$ of the silty and clayey materials on the surface during the first runoff event. During the rest of the runoff events, the spillway would have accumulated between $60 \%-90 \%$ of the suspended load. A sand storage dam filled during these bedload transport conditions would have been severely affected by siltation. The results of this study are in line with these types of bedload transport conditions. However, further research is still required to compare the performance of one-stage and multi-stage sand storage dams under similar rainfall, runoff, and sediment transport conditions, and to analyze the correlation of the spillway height, the variability of the bedload transport, the

Table 6

Classification of the capacity to produce sand sediment of each study site.

\begin{tabular}{llll}
\hline & No capacity & Moderate capacity & Satisfactory capacity \\
\hline & & & \\
Sand storage & $9-11,17$ & $2,4,12,15,16,18-$ & $1,3,5-8,13,14,22,23,25-$ \\
$\quad$ dam & & 21,24 & 30 \\
Total SDs & 4 & 10 & 16 \\
Total (\%) & $14 \%$ & $33 \%$ & $53 \%$ \\
\hline
\end{tabular}

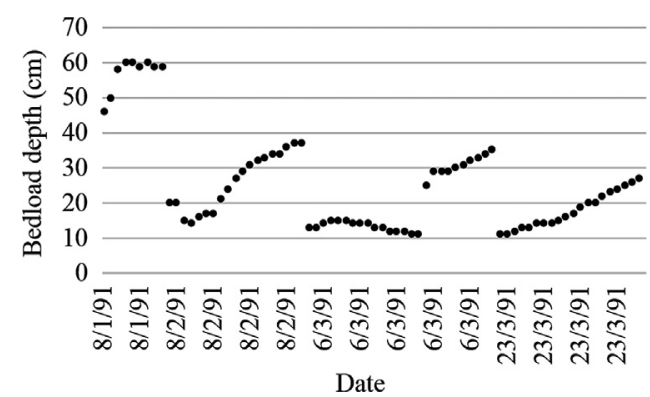

Fig. 5. Variability of the bedload transport at inter- and intra-annual levels. Source: Adapted from Reid et al. (1995). siltation extent and the performance between these two design approaches.

\subsubsection{Forced joint deposition of coarse and fine grain sediment}

The shallow depths of sand in the study area suggest the presence of inter-bedded layers of alluvium sediment of different grain sizes (i.e. graded-bedded reservoirs). These inter-bedded layers are result of the forced joint deposition of coarse and fine grain sediment transported in the runoff because of the height of the one-stage spillway. In a few cases, this layered deposition may have been reinforced by the presence of upstream sand storage dams blocking any available bedload. Furthermore, the large volumes of fine grain sediment in the reservoirs did not auto- matically imply that the catchment areas did not have the capacity to produce sand sediment, as most of the study sites had the natural capacity to produce sand. Thus, Table 6 classifies the sites according to the capacity to produce sand sediment after con- sidering the measured width and depth of sand, the predominant sediment texture, and the actual and maximum sand storage capacity of the sand storage dams. In order to classify the capacity to produce sand sediment of each study site, a moderate capacity to produce sand sediments was associated with low widths ( $05 \mathrm{~m}$ ) and shallow depths ( $01 \mathrm{~m}$ ) of sand sediments (Nissen- Petersen, 2000) coupled with predominant fine grain sediment texture (silt- and clay-like) in the reservoirs and low sand storage capacities.

\subsubsection{Clogging of coarse sand sediment with fine grain particles}

The measured average specific yield in the study area (7\%) was

in the range of the minimum specific yield for fine sand, and the maximum specific yields for silty and sand-silt-clay mixtures (Brassington, 2007; Johnson, 1967; Morris \& Johnson, 1967). Thus, the individual specific yield of the sand samples was between 3 and 5 times lower than the satisfactory specific yield for sand reservoirs, which Wipplinger (1958) proposed to be $20-25 \%$. The low specific yield values were caused by the clogging of coarse sand sediment with fine grain particles. Hence, as long as there was any joint deposition of sandy, silty, and clayey alluvium sediment, or where layers of sand were permanently or temporally filled with finer materials, silt- and clay-like particles had the potential to clog the spaces between coarse sand particles and form confining layers. Thereby, producing specific yields lower than their potential specific yield (Brassington, 2007; Helweg \& Smith, 1978; Hussey, 2007). This was consistent with the on-theground surveys, because the reservoirs did show clear signs of a joint deposition of sand and fine grain sediment (Fig. 6).
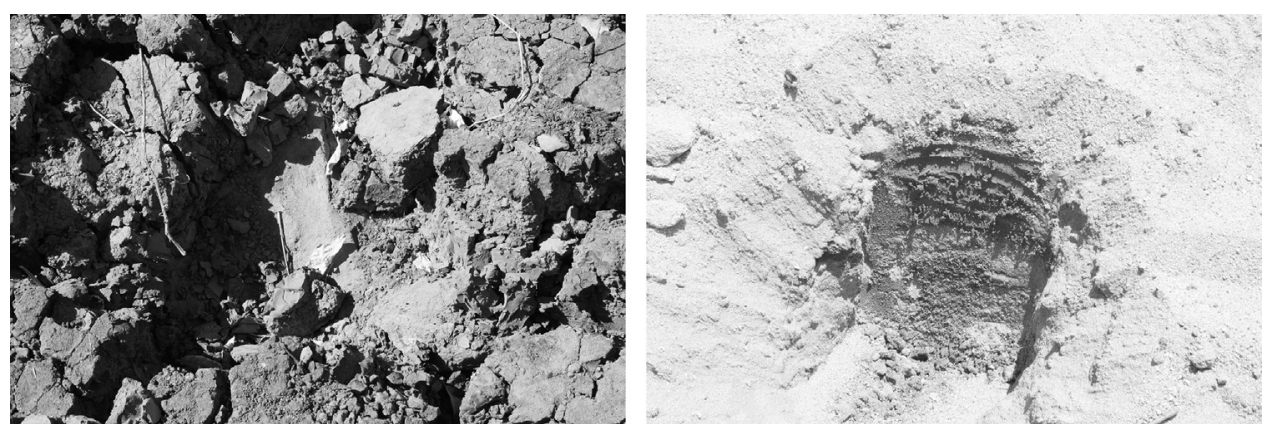

Fig. 6. Graded-bedded and clogged reservoirs. A layer of silty alluvium sediment on top of sand (left) and a layer of sand on top of clayey sediment (right), which were clogging the sand reservoir with clay- and silt-particles. 


\subsection{Systematically minimizing the risk of siltation to optimize} performance

The bedload transport is highly variable, often non-existent, inter- and intra-annually in arid and semi-arid areas, corre- sponding to a minor fraction of the total sediment yield. In addi- tion, the height of the spillway increases the deposition of fine grain sediment in the reservoir. These hydrogeological arguments are also true for sites with the geological potential to produce coarse sand sediment (Alexandrov et al., 2003, 2009; Lucia et al., 2013). Therefore, the lower the stage height, the lower the vul- nerability to siltation and the higher the probability of maximizing the exclusive accumulation of the bedload transport despite its inter- and intra-annual variability. Thus, a multi-stage spillway construction process, with stages of reduced height, maximizes performance, cost-efficiency, and positive impacts across many different environmental settings despite the variability of rainfall, runoff, and bedload transport in arid and semi-arid areas (De Trincheria et al., 2015, 2016).

To determine a stage height that can systematically minimize siltation at the same time as the exclusive accumulation of the coarsest sediment in the runoff is maximized, despite the bedload transport variability, is the most challenging design criteria of a multi-stage sand storage dam. Thus, De Trincheria et al. (2016) recommended that the best possible practice was to determine the specific stage height on a case-by-case basis through a long-term analysis of the bedload transport. If it is not feasible to carry out a multi-year analysis of the bedload transport at a specific site, De Trincheria et al. (2016) developed a preliminary methodology for practitioners to use a range of fixed stage heights from $20 \mathrm{~cm}$ to 60 $\mathrm{cm}$ on a case-by-case basis after reviewing 50 years of relevant scientific literature on the spillway design of sand storage dams and bedload transport in arid and semi-arid areas.

Despite the benefits of the multi-stage spillway design, there is currently an almost absolute predominance of the one-stage design. In many cases, implementing agencies may be well aware of the inherent benefits of building in stages, and the high risk of siltation associated to the one-stage spillway design, but the donor-based nature of most implementing agencies often dictates to complete activities and report results within the conventional project periods of 1 to 3 years. This may be coupled with the generalized misconception that a multi-stage spillway design necessarily involves construction periods higher than 1 to 3 years, and higher construction costs than the one-stage design (De Trincheria et al., 2016). Therefore, most implementing agencies may wrongly assume that raising the spillway in stages of reduced height is not feasible from a project management viewpoint. This assumption is made in spite of very few cases of the same implementing agencies actually having built a sand storage dam in stages. This is also in spite of the existence of several high-per- forming sand storage dams which have been built by stages of reduced height within conventional project periods. Furthermore, the actual existence of several onestage sand storage dams which are working satisfactorily may further blur the need for a multi- stage spillway design. In some other cases, implementing agencies may be unaware or lack an adequate understanding of the high risk of siltation associated with one-stage spillway design. In addition, some implementing agencies may be unaware of the benefits of building in stages or lack the technical capacity to adequately implement a multi-stage spillway design.

\subsection{Estimation of the number of silted-up sand storage dams}

A very significant number of sand storage dams built in onestage all over sub-Saharan Africa may be performing well below their technical optimum, which in many cases may not be enough to meet local community needs during the entire dry season. This is line with reported failure rates for sand storage dams in the range of $50 \%$ in Kenya (Viducich, 2015). However, this may be a conservative failure rate, taking into account the high variability of the bedload transport in arid and semi-arid areas at an inter- and intra-annual level, and the absolute predominance of sand storage dams built in one-stage with a final spillway height that is usually between 1 and $5 \mathrm{~m}$.

Considering the variability of the bedload transport and the wide replication of the one-stage spillway design, it is estimated that the number of one-stage sand storage dams which may be affected by siltation may not be lower than $60 \%$ in sub-Saharan Africa, in general, and Kenya in particular. In Kenya alone, this could imply that 1800 out of the 3000 sand storage dams built may be severely affected by siltation. Furthermore, to system- atically have raised the spillway in stages of reduced height could have ensured optimal performance. Thus, if the sand reservoir exhibiting the highest water yield in this study $\left(2400 \mathrm{~m}^{3} / \mathrm{y}\right)$ is taken as an indication of the potential performance of a multi- stage construction process with stage heights of $20 \mathrm{~cm}$, it is esti- mated that annual yields and supply capacities 26 times higher would have been produced in the study area, as long as the bed- load layer height would not have been lower than $20 \mathrm{~cm}$ during the filling of the reservoirs. This would have implied that the 30 reservoirs evaluated would have had the capacity to supply 8,516 people as compared to the current supply capacity of 330 people.

\subsection{Applicability to other arid and semi-arid areas}

The generalized poor performance and insufficient positive impacts on local communities obtained in this study should not be taken as an indicative for all one-stage sand storage dams. Thus, the same variability of the sediment transport that leads to bed- load transport rates lower than the height of the one-stage spill- way can also produce bedload transport rates higher than the height of the one-stage spillway, which may lead to higher per-formance levels and benefits to local communities. Notwith- standing, the results of this study are applicable to an estimated $60 \%$ of sand storage dams affected by siltation in arid and semi- arid areas. Thus, the study area was of strategic interest, as it allowed evaluation of the performance of one-stage sand storage dams that suffered from highly variable bedload transport condi- tions during the filling of the reservoir, which is an inherent risk for arid and semi-arid areas. Due to this variability, any environ- mental setting with the capacity to produce sand sediment is highly vulnerable to siltation.

Furthermore, due to the spillway height and the high inter- and intra-annual variability of the bedload transport in arid and semiarid areas, the one-stage spillway design has an inherent, high vulnerability to accumulate large volumes of fine grain sediment which is transported as part of the suspended load in the runoff. Thereby, siltation of the reservoir is induced, despite the geological potential of a site to produce sand sediment. As southeastern Kenya is a worldwide hotspot in the use of this spillway design, which has been widely replicated in other arid and semi-arid areas of subSaharan Africa, southeast Asia, and Latin America, the large number of sand storage dams affected by siltation in Kenya may be highly representative of other arid and semi-arid areas. Therefore, the results and practical recommendations of this study are highly applicable to other arid and semi-arid areas.

\section{Conclusions}

Sand storage dams can provide an important contribution towards fostering food security and poverty alleviation and 
increasing the resilience of rural communities to climate varia- bility and change. However, much research and substantial improvements in the design of sand storage dams are needed. Among these needs, it is necessary to understand sand storage dams as a hydraulic retention structure that must be designed to maximize the exclusive accumulation of coarse sand sediment that are transported as part of the bedload. In addition, sand storage dams must be designed to minimize the accumulation of fine grain sediment that is transported as part of the suspended load. Furthermore, the influence of the variability of the bedload transport on the siltation of sand storage dams and its association with poor performance levels also need to be considered.

Most of the one-stage sand storage dams evaluated as part of this study were severely affected by siltation and performed poorly, both in terms of their technical optimum and meeting local community needs. The primary driving factor that caused siltation and the associated poor performance of the sand storage dams evaluated was the inherent high variability of the bedload transport at an inter- and intra-annual level. This variability, coupled with the construction of one-stage spillways, led to the accumu- lation of large volumes of fine grain sediment transported as part of the suspended load during runoff events with bedload layer heights lower than the height of the one-stage spillways.

This study does not recommend stopping investing in sand storage dams, but there is a need to invest in sand storage dams that are resilient to the variability of the bedload transport and can ensure the highest probability to perform optimally in as many different environmental settings and/or rainfall, runoff, and sedi- ment transport conditions as possible. To build a sand storage dam in stages of reduced height maximizes their robustness to the bedload transport variability and minimizes vulnerability to sil- tation. The strategic advantage of multi-stage construction in arid and semi-arid areas is crucial to systematically ensure optimal performance levels and successfully replicate, transfer, and upscale this technology to other arid and semi-arid areas, helping rural areas of low-income economies to address the many challenges that water shortages pose to them.

\section{Acknowledgments}

The authors are grateful to Onesmus Musyoka and Erik NissenPetersen for their assistance in the field, and Professor Menas Wuta for proofreading the manuscript. The authors would like to gratefully acknowledge the critical evaluation and constructive feedback of the anonymous reviewers of this manuscript. This research has not been funded by any organization. The authors encourage donor organizations to contact us to scale up this research.

\section{References}

Alexandrov, Y., Cohen, H., Laronne, J. B., \& Reid, I. (2009). Suspended sediment load, bed load, and dissolved load yields from a semiarid drainage basin: A 15-year study. Water Resources Research, 45, 8 .

Alexandrov, Y., Laronne, J. B., \& Reid, I. (2003). Suspended sediment transport in flash floods of the semi-arid northern Negev, Israel. International Association of Hydrological Sciences Publication, 278, 346-352

Batchelor, C., Fonseca, C., \& Smits, S. (2011). Life-cycle costs of rainwater harvesting system. Occasional Paper 46. The Hague, The Netherlands: IRC International Water and Sanitation Centre, WASHCost and RAIN. Retrieved from 〈http:// www.irc.nl/op46>

Baurne, G. (1984). "Trap-dams": Artificial subsurface storage of water. Water International, 9(1), 2-9.

Borst, L., \& De Haas, S. A. (2006). Hydrology of Sand Storage Dams. A case study in the Kiindu Catchment, Kitui District, Kenia (MSc Thesis). The Netherlands: Faculty of Earth and Life Sciences, Vrije Universiteit Amsterdam.
Brassington, R. (2007). Field hydrogeology ((3rd ed.). Chichester, England: John Wiley \& Sons.

Cantalice, J. R. B., Cunha Filho, M., Stosic, B. D., Piscoya, V. C., Guerra, S. M., \& Singh, V. P. (2013). Relationship between bedload and suspended sediment in the sand-bed Exu River, in the semi-arid region of Brazil. Hydrological Sciences Journal, 58(8), 1789-1802.

Chenoweth, J. (2008). Minimum water requirement for social and economic development. Desalination, 229(1-3), 245-256.

De Trincheria, J., Nissen-Petersen, E., Leal Filho, W., \& Otterpohl, R. (2015). Factors affecting the performance and cost-efficiency of sand storage dams in southeastern Kenya. In E-proceedings of the 36th IAHR World Congress, The Hague, The Netherlands, 28 June -3 July 2015.

De Trincheria, J., Wibbing, J., Leal Filho, W., \& Otterpohl, R. (2016). . Practical recommendations to prevent, restore and rehabilitate silted-up sand storage dams in arid and semi-arid areas. In E-proceedings of the 7th RWSN Forum "Water for Everyone", Abidjan, Côte d'Ivoire, 29 Nov - 02 Dec 2016.

Forzieri, G., Gardenti, M., Caparrini, F., \& Castelli, F. (2008). A methodology for the preselection of suitable sites for surface and underground small dams in arid areas: A case study in the region of Kidal, Mali. Physics and Chemistry of the Earth, Parts A/B/C, 33(1), 74-85.

Gichuki, F.N. (2000). . Makueni district profile: Rainfall variability, 1950-1997. Dryland Research Working Paper no. 2. Somerset, England: Drylands Research

Government of Kenya (GoK) (2009a). Ministry of Information, Communication and Technology: Household access to water by sublocation, 2009. Kenya open data. Retrieved from 〈https://www.opendata.go.ke/Water-andSanitation/Housh eold-Access-To-Water-By-Sublocation-2009/g3dc$\mathrm{dk} 7 \mathrm{w}\rangle$

GoK. (2009b). Ministry of Information, Communication and Technology: Livestock population by type and district, 2009. Kenya open data. Retrieved from 〈https:// www.opendata.go.ke/Agriculture/Livestock-population-by-type-and-district/ gmcn-ykjy>

GoK. (2012a). The short rains season assessment report. Nairobi, Kenya: Government of Kenya. Retrieved from 〈http://www.humanitarianresponse.info/sites/www. humanitarianresponse.info/files/assessments/SRA\%2BFinal\%2BReport.pdf〉.

GoK. (2012b). The long rains season assessment report. Nairobi, Kenya: Government of Kenya. Retrieved from 〈http:/ / www.disasterriskreduction.net/fileadmin/ user_upload/drought/docs/2012\%20Kenya\%20Long\%20Rains\%20Assessment\% 20Report_Final.pdf $>$

Heath, R.C. (1987). . Basic ground-water hydrology. U.S. Geological Survey WaterSupply Paper 2220, Reston, VA, U.S.

Hellwig, D. (1973). Evaporation of water from sand, 4: The influence of the depth of the water-table and the particle size distribution of the sand. Journal of Hydrology, 18(3), 317-327.

Helweg, O. J., \& Smith, G. (1978). Appropriate technology for artificial aquifers. Groundwater, 16(3), 144-148.

Hussey, S.W. (2007). . Water from sand rivers: Guidelines for abstraction. Water Engineering and Development Centre (WEDC), Loughborough University, U.K. Produced in association with Dabane Trust, Zimbabwe and WETT, U.K.

Hut, R., Ertsen, M., Joeman, N., Vergeer, N., Winsemius, H., \& van de Giesen, N. (2008). Effects of sand storage dams on groundwater levels with examples from Kenya. Physics and Chemistry of the Earth, Parts A/B/C, 33(1), 56-66.

Jaafar, H. (2014). Feasibility of groundwater recharge dam projects in arid environments. Journal of Hydrology, 512, 16-26.

Johnson A.I. (1967). Specific yield - compilation of specific yields for various materials. U.S. Geological Survey. Water-Supply Paper 1662-D, Reston, VA, U.S.

Knoop, L., Sambalino, F., \& van Steenbergen, F. (2012). Securing water and land in the Tana basin: A resource book for water managers and practitioners. Wageningen, The Netherlands: 3R Water Secretariat.

Lasage, R., Aerts, J., Mutiso, G., \& De Vries, A. (2008). Potential for community-based adaptation to droughts: Sand storage dams in Kitui, Kenya. Physics and Chem istry of the Earth, Parts $A / B / C, 33(1), 67-73$.

Lasage, R., Aerts, J. C., Verburg, P. H., \& Sileshi, A. S. (2015). The role of small-scale sand storage dams in securing water supply under climate change in Ethiopia. Mitigation and Adaptation Strategies for Global Change, 20(2), 317-339.

Lasage, R., \& Verburg, P. H. (2015). Evaluation of small-scale water harvesting techniques for semi-arid environments. Journal of Arid Environments, 118, 48-57.

Lawrence, P., \& Lo Cascio, A. (2004). Sedimentation in small dams: Hydrology and drawdown calculations. Wallingford, U.K: HR Wallingford Ltd and Department for International Development.

Lucia, A., Recking, A., Martín-Duque, J. F., Storz-Peretz, Y., \& Laronne, J. B. (2013) Continuous monitoring of bedload discharge in a small, steep sandy channel. Journal of Hydrology, 497, 37-50

Morris, D.A., \& Johnson, A. (1967). . Summary of hydrological and physical prop- erties of rock and soil materials as analysed by the Hydrologic Laboratory of the U.S. Geological Survey 1948-60. U.S. Geological Survey Water-Supply Paper 1839-D, Reston, VA, U.S.

Morris, B.L., Lawrence, A.R.L., Chilton, P.J.C., Adams, B., Calow, R.C., \& Klinck, B.A. (2003). . Groundwater and its susceptibility to degradation: A global assess- ment of the problem and options for management. Early Warning and Assess- ment Report Series, RS 03-03. United Nations Environment Programme, Nairobi, Kenya.

Nilsson, A. (1988). Groundwater dams for small-scale water supply. London, U.K Intermediate Technology Publications.

Nissen-Petersen, E. (2000). Water from sand rivers. A manual on-site survey, design, construction and maintenance of seven types of water structures in riverbeds. Regional Land Management Unit (RELMA), Technical Handbook No. 23. Nairobi, Kenya. 
Nissen-Petersen, E. (2006). Water from dry riverbeds. How dry and sandy riverbeds can be turned into water sources by hand-dug wells, subsurface dams, weirs and sand storage dams. ASAL Consultants Limited for the Danish International Development Assistance, Nairobi, Kenya.

Nissen-Petersen, E. (2011). Sand storage dams or silt traps? ASAL Consultants Lim- ited. Retrieved from 〈http://Www.samsamwater.com/library/Sand_dams_or silt_traps.pdf $>$.

Ochieng, G.M., Otieno, F.A., Shitote, S.M., \& Sitters, C.C. (2008). Investigating the effect of step height increment, channel slope, and flow rate on specific yield of sand storage dams. Retrieved from 〈http://www.ewisa.co.za/literature/files/ ID56\%20Paper84\%20Ochieng\%20G.pdf〉.

Okun, D. A., \& Ernst, W. R. (1987). Community piped water supply systems in developing countries: A planning manual (Technical Paper 60). Washington D.C., U.S: World Bank.

Pachauri, R. K., Allen, M. R., Barros, V. R., Broome, J., Cramer, W., Christ, R., \& Dubash, N. K. (2014). In: R. Pachauri, \& L. Meyer (Eds.), Climate change 2014: Synthesis report. Contribution of Working Groups I, II and III to the Fifth Assessment Report of the Intergovernmental Panel on Climate Change (IPPC). Geneva, Switzerland: IPCC.

Reid, I., \& Frostick, L. E. (2011). Channel form, flows and sediments of endogenous ephemeral rivers in deserts In: D. S.G. Thomas (Ed.), Arid zone geomorphology: Process, form and change in drylands (3rd Edition). Chichester, U.K.: John Wiley \& Sons, Ltd.

Reid, I., Laronne, J. B., \& Powell, D. M. (1995). The Nahal Yatir bedload database: Sediment dynamics in a gravel-bed ephemeral stream. Earth Surface Processes and Landforms, 20(9), 845-857.

Rocheleau, D., Benjamin, P., \& Diang'a, A. (1995). The Ukambani region of Kenya In: J. X. Kasperson, R. E. Kasperson, \& B. L. Turner, B. L., II (Eds.), Regions at Risk: Comparisons of Threatened Environments. Tokyo: United Nations University (Available

〈http://archive.unu.edu/unupress/unupbooks/uu14re/uu14re0j. htm $\mathrm{at}$
Rockström, J., \& Falkenmark, M. (2015). Increase water harvesting in Africa. Nature, $519,283-285$

Sawunyama, T., Senzanje, A., \& Mhizha, A. (2006). Estimation of small reservoir storage capacities in Limpopo River basin using geographical information systems (GIS) and remotely sensed surface areas: Case of Mzingwane catchment. Physics and Chemistry of the Earth, Parts A/B/C, 31(15), 935-943.

Stephens, T. (2010). Manual on small earth dams: A guide to siting, design and construction. Rome: Food and Agriculture Organization of the United Nations.

Studer, M., \& Liniger, H. (2013). Water harvesting: Guidelines to good practice. Centre for Development and Environment (CDE), Bern; Rainwater Harvesting Implementation Network (RAIN), Amsterdam; MetaMeta, Wageningen; International Fund for Agricultural Development (IFAD), Rome, Italy.

Tuinhof, A., van Steenbergen, F., Vos, P., \& Tolk, L. (2012). Profit from storage. The costs and benefits of water buffering. Wageningen, The Netherlands: 3R Water Secretariat. United Nations Millennium Development Goals (2015).

Viducich, J. (2015). Spillway staging and selective sediment deposition in sand storage dams (MSc Thesis). Oregon, U.S: Department of Water Resources Engineering, Oregon State University.

Wheater, H., \& Al-Weshah, R.A. (2002). Hydrology of wadi systems. IHP regional network on wadi hydrology in the Arab region. UNESCO, Paris: Technical documents in hydrology (No. 55).

Wipplinger, O. (1958). Storage of water in sand. South West Africa Administration Water Affair Branch. Windhoek, Namibia.

World Health Organization (WHO) (2005). Minimum water quantity needed for domestic uses. WHO/SEARO, Technical Notes for Emergencies. Retrieved from 〈http:/ / ec.europa.eu/echo/files/evaluation/watsan2005/annex_files/WHO/ WHO5\%20-\%20Minimum\%20water\%20quantity \%20needed $\% 20$ for $\% 20$ domestic \%20use.pdf〉. 